\title{
DYNAMICS AND INTERFACE DEFOLIATION GRAZING: REVIEW
}

Patrick Bezerra Fernandes, Antonio Leandro Chaves Gurgel, Emizael Menezes de Almeida, Lucélia de Fátima Santos, Rodrigo Amorim Barbosa

Universidade Federal do Mato Grosso do Sul - UFMS. E-mail: zoo.patrick@hotmail.com

\begin{abstract}
In the last five decades researchers have attempted to explain how adaptations of the morphology of the mouth and digestive tract of large ruminants interact with different food scales in the pasture ecosystem independent of the grazing method, thus understanding the dynamics of defoliation is essential in the analysis of response variations in forage production. A brief review of the literature on the factors related to the animal and plant components, influence of the grazing process and the defoliation dynamics will be presented. Grazing is the fundamental procedure that influences the dynamics and functioning of pasture ecosystems. The structural components of the tiller present in the horizontal plane of the forage canopy are likely to lead to differences in resource exploitation and impacts on vegetation, and many variables should be analyzed to fully understand the defoliation, since variations in canopy architecture are also influenced by the grazing method itself, which modifies the harvest and use of forage. In different grazing methods, it was observed that defoliation behaves in an analogous way among the methods, considering that the only variation was in the number of grazing animals, that is, changes in the stocking rate. The level of defoliation of individual tiller and its respective structural components, coupled with the grazing process, allows us to understand how the management of the pasture by adjusting the animal load influences the choices of the animals during the forage harvesting process.
\end{abstract}

Keywords: animal; frequency; management.

\section{DINAMICA DE DESFOLHAÇÃO E INTERFACE DO PASTEJO: REVISÃO}

\section{RESUMO}

Nas últimas cinco décadas os pesquisadores tentam explicar como as adaptações da morfologia da boca e do trato digestório de grandes ruminantes interagem com diferentes escalas de alimentos no ecossistema pastagem independente do método de pastejo. Assim a compreensão da dinâmica da desfolhação é essencial na análise das variações de respostas na produção de forragem. Diante disso será apresentada uma breve revisão de literatura sobre os fatores relacionados ao componente animal e vegetal, influencia o processo de pastejo e a dinâmica de desfolhação. O pastejo é o procedimento fundamental que influencia a dinâmica e o funcionamento dos ecossistemas de pastagens. Os componentes estruturais do perfilho presentes no plano horizontal do dossel forrageiro são susceptíveis a conduzir diferenças na exploração dos recursos e os impactos sobre a vegetação, e muitas variáveis devem ser analisadas para compreender plenamente a desfolha, uma vez que variações na arquitetura do dossel também são influenciadas pelo próprio método de pastejo, que modifica a colheita e utilização de forragem. Em diferentes métodos de pastejo, observou que, a desfolhação se comporta da forma análoga entre os métodos, tendo em vista que a única variação era no número de animais em pastejo, ou seja, variações na taxa de lotação. A abrangência em nível de desfolhação de perfilho individual e seus respectivos componentes estruturais aliados ao processo de pastejo permitem compreender como o manejo do pasto por meio do ajuste na carga animal influencia nas escolhas dos animais durante o processo de colheita de forragem.

Palavras - chave: animal; frequência; manejo. 


\section{INTRODUCTION}

In the last five decades, forage farming has evolved in relation to pasture management from the debate about the importance of adjusting the stocking density in each grazing method, and how this adjustment impacts on animal production (BRISKE et al., 2008; WADE, 1991).

The researchers attempted to explain how adaptations of the morphology of the mouth and digestive tract of large ruminants interact with different food scales in the pastureindependent pasture ecosystem (GORDON, 2003), the animal performing the morsel, encounters a horizontal plane quite heterogeneous in both cultivated pastures and native fields (e.g. live leaf blades, senescent leaf blades and stalks in tropical climate grasses).

The structural components of the plant can be used as an objective measure in the study of the harvesting process and the use of fodder produced (GRIFFITHS et al., 2003). This is because, there are large differences in the quantity and quality of the nutritive value of these components (ROMERA et al., 2012; STOBBS, 1973). A significant factor in the ingestive behavior of ruminants under grazing and, consequently, also has an impact on the performance of the animal (BRISKE et al., 2008, CARVALHO, 2013; LEMAIRE et al., 2009).

The canopy structure in tropical climate grasses has a great influence on the depth of the pasture; in these pastures, the mass is reduced by the reduction in the depth of the bit because of the stalks, increasing the time of grazing, rumination and limiting the food intake by the animals, as well as to perform in smaller performances (CHACON; STOBBS, 1976; HODGSON et al., 1994).

The dynamics of defoliation can aid in the understanding of plant and animal interaction, there is a conceptual basis for the causal relationships between pasture structural characteristics and forage consumption (HODGSON, 1985), characterizing in terms of frequency, plant defoliation severity in the pasture ecosystem (FONSECA et al., 2012; MEZZALIRA et al., 2014), being related to the spatial distribution of biomass among grazing areas.

Raising the hypothesis that herbivorous foragers have mechanisms (smell) that allow better perception of how much plants offer nutrients, being influenced by the perception and distribution of resources in the ecosystem, influencing the decision made by the animal at different spatial and temporal scales during the period of grazing.

Thus understanding the dynamics of defoliation is essential in the analysis of the variation of responses in forage production and, consequently, in animal production, since they presuppose that forage plants with distinct structural characteristics can be defoliated in the same proportion. A brief review of the literature on the factors related to the animal and plant components, influence of the grazing process and the defoliation dynamics will be presented.

\section{THE GRAZING PROCESS}

Grazing is the fundamental procedure that influences the dynamics and functioning of pasture ecosystems (BRISKE et al., 2008; CARVALHO et al., 2009), a process by which animals use their senses, head, legs and parts of the mouth (tongue) to remove plant tissue from the plant, hold it between the teeth, cut with head movement, chew to form cakes and swallow. However, it is a process that undergoes strong influence of the structure / quality of the plant (CHIRAT et al., 2014).

Forage quality, such as the proportion of high quality plant parts (green leaf blades) and the spatial distribution pattern, has marked effects on the rate of forage consumption by cattle. These effects are caused by the strong negative response in the size of some structural components of the plant (stem), causing more passive defoliation (DRESCHER et al., 2006).

The more active defoliation causes the differential removal of tissues, altering vegetation competition and plant growth patterns; and the structure of the pasture is altered by the defoliation event (BARBOSA et al., 2007; CARVALHO et al., 2009).

Therefore, the structural components of the tiller present in the horizontal plane of the forage canopy are likely to lead to differences in resource exploitation and impacts on vegetation, and many variables should be analyzed to fully understand the defoliation (PIERSON; SCARNECCHIA, 1987). According to Agnusdei (1999), the main difficulty in understanding the interactions between the plant and the animal is the basic factor of studying scales of the structural components of the individual tiller (Figure 1), being the basic units to connect animal consumers to communities of plants. 
Figure 1. Schematic representation of grazing zones grasses are structural components of the tiller: leaf in expansion (a), expanded (b), senescent (c) and stem (d). [Source: adapted from AGNUSDEI, (1999), HODGSON, (1990), NABINGER and BRIDGES (2001) and WADE (1991)].

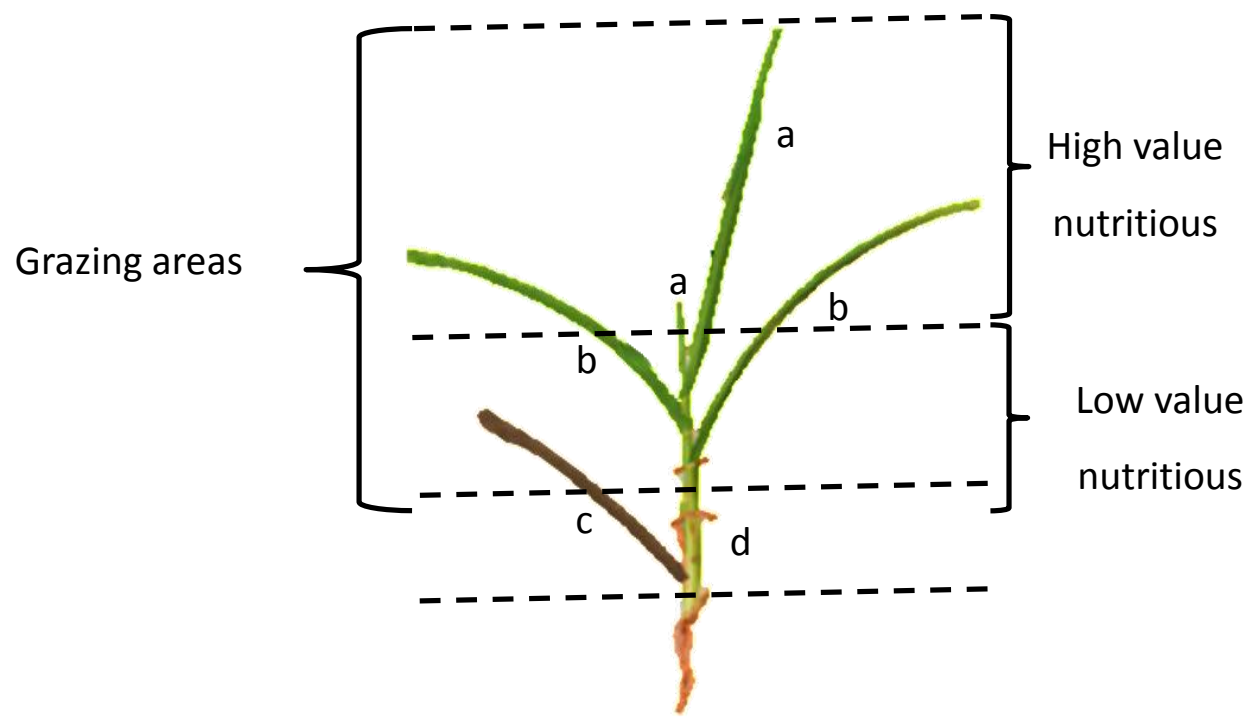

According to Hodgson (1990), grazing animals present more consistent responses to variations in height and structural components of the forage canopy (Figure 1), than forage density, is generally related to the ease of harvesting and seizing forage during grazing. This is because the structural characteristics determine the degree of grazing and selectivity, and which components will be part of the mass of the morsel, and after defoliation, the animal modifies the composition of the remaining tissues, altering the environment of the future morsel (CARVALHO et al., 2009).

In this study, the use of forage in the canopy of the canopy was also influenced by the grazing method (LEMAIRE et al., 2009). However, when the herbivore is allocated in an area that has been subdivided, in the first days of grazing there is a supply of leaves, however as the period of occupation increases, the availability of green leaves decreases, and the animal is forced to (BAKER et al., 2009), and to reduce the amount of dry matter consumed. These fluctuations in the supply of food during the period of occupation may alter the mass of the morsel (SILVA; CARVALHO, 2005), however it is still unclear whether there will be changes in defoliation.

\section{DEFOLIATION FREQUENCY}

The frequency of defoliation can be comprised between the interval of two defoliation and / or number of visits that a tiller and its respective components receive at each grazing event (LEMAIRE et al., 2009). It can also be represented by the average probability of a tiller or leaf being touched by the animal during the grazing period, representing the "horizontal" size of the defoliation (AGNUSDEI, 1999).

Defoliation events Can't be understood at plant level in response to abiotic factors, according to Mazzanti and Lemaire (1994), studying Festuca arundinacea submitted to different doses of nitrogen $(\mathrm{N})$ the doses did not influence the frequency of defoliation of extended tiller. However, to maintain a similar pasture height, treatments with higher $\mathrm{N}$ levels required higher stocking densities.

Wade (1991), in different grazing methods, observed that defoliation behaves in an analogous way between the methods, considering that the only variation was in the number of grazing animals, that is, changes in the stocking rate.

According to Briske et al. (2008), the pasture manager should pay more attention to the stocking density, since it is one of the main determinants for the balance of plant and animal production. According to Lemaire et al. (2009), corroborating with Briske et al. (2008) and following Wade (1991) hypothesis, it is undisputed that defoliation of individual tillers is closely linked to stocking density, however, it is necessary to study in more detail the functional meaning of the general relation between frequency of defoliation and density of and in the 
distribution of the components of the tiller in the horizontal grazing plane (AGNUSDEI, 1999).

It is important to note that, depending on the instantaneous stocking density applied, all individual tills or sheets are not necessarily touched on the same scale (HODGSON, 1966). Thus, the relative position of different leaves in the canopy can be very different, depending on the species and the plant communities, resulting in variations in defoliation patterns (LEMAIRE et al., 2009).

The growing leaves are less defoliated than mature leaves, since they are smaller and younger, being more evident in a continuous grazing system due to the balance between the population of tillers and leaf length (CURLL; WILKINS, 1982; LEMAIRE et al., 2009). However, in intermittent stocking, depending on the management protocol used, it is possible to notice that the growing leaves are in the same grazing zone as the fully expanded leaves (Figure 1), so it can be assumed that they will be touched by the herbivores with the same proportion as mature green leaves (AGNUSDEI, 1999).

The senescent leaves have angles of insertion in the increasingly horizontal tiller, reducing their accessibility to the higher layers of the vegetation cover, compared to the adult leaves and the young ones that have a much more vertical point (HODGSON, 1966; MAZZANTI; LEMAIRE, 1994). For the Brachiaria Marandu (GONÇALVES, 2002) and BRS Tupi (MIQUELOTO, 2013) among the foliar categories, the senescent leaves are 2.6 to 7.8 times less defoliated when compared to the mature leaves, ruminants generally have preference (BAUMONT et al., 2004). In addition, it is important to note that the use

Therefore, the plant cover structure in particular, the final leaf size, its insertion angle and its position in the vegetative cover can help to understand the possible differences that may exist in the frequency of defoliation in the horizontal grazing plane (HODGSON, 1990).

\section{DEFOLIATION SEVERITY}

Defoliation severity is the final product of the functional relationship of defoliation frequency and stocking density, and can be defined by the individual leaf scale as the ratio between the average leaf length that was harvested (DERNER et al., 1994; LEMAIRE et al., 2009). This quantity, expressed as the percentage of leaf length consumed by the animal, represents the "vertical" component of defoliation (AGNUSDEI, 1999).

Wade (1991) points out that the defoliation intensity, estimated on the basis of the height of the extended tillers, was the constant proportion of $35 \%$ over a wide range of height in relation to the level of stocking density, and this ratio remained in the same condition in Lolium perenne pastures under continuous stocking. Thus, it is likely that variations in defoliation intensity obtained from a proportion of removed tissue may reflect on the vertical structure of the vegetative cover in the same proportion as the height of the defoliated extended tiller does not correspond to the same proportion of tissue of the removed leaf.

The length of the leaf that is consumed on average for each event / touch of defoliation, is about $50 \%$ of the leaf initial length and can be altered according to the height and structure of the plant (HODGSON, 1966; MAZZANTI; LEMAIRE, 1994).

The defoliation of fully expanded leaf blades is reduced with increasing canopy height, as a result of increased consumption of expanded leaf blades, longer and more easily apprehended (PALHANO et al., 2005). In general, about $70 \%$ of leaf length is consumed when pasture is kept at low altitude by high stocking density, while only $40 \%$ of leaf length is consumed when pasture is managed at low stocking rates (LEMAIRE et al., 2009).

The differences in the developmental stage of the plants within the same forage species limit the depth of the bit, due to the stiffening and elongation of the stalks (BENVENUTTI et al., 2009; SILVA et al., 2009). Studies examining the relationship between bit depth and stem in the lower strata under controlled conditions are few, although the increasing role of structural complexity is increasingly widely recognized.

According to Griffiths et al. (2003), the stump is just a partial bit depth partial governor. According to Bakker et al. (1998), the proportion of ryegrass stem was very low in diets for sheep and guanacos. The authors reported that, with the increase in the proportion of grazing horizons, there is less consumption and participation of stem in the diet, and it is not related to the restrictive effect in the bit depth, but possibly to the ingestive behavior, selectivity and bit height. 
Barbosa et al. (2007) and Tuñon et al. (2003), suggest the use of more rigorous grazing intensities, to control the stem elongation, stabilizing the number of tillers, resulting in a larger number of growing leaves. Sbrissia et al. (2009), warned that the constant use of this strategy could lead to pastures to collapse, with the need to replenish more nutrients in the soil, increasing the costs related to the maintenance and fertilization of pastures, negatively impacting the performance of the animals and plant regeneration process (RODOLFO et al., 2015).

\section{CONCLUSION}

The level of defoliation of individual tiller and its respective structural components allied to the grazing process allow to understand how the management of the grass through the adjustment in the animal load influences the choices of the animals during the process of forage harvesting.

\section{REFERENCES}

AGNUSDEI, M. Analyse de la dynamique de la morphogenèse foliaire et de la défoliation de plusieurs espèces de graminées soumises à un pâturage continu dans une communauté végétale de la pampa humide(argentine). 1999. Tese de Doutorado.

BAKKER, M. L.; GORDON, I. J.; MILNE, J. A. Effects of sward structure on the diet selected by guanacos (Lama guanicoe) and sheep (Ovis aries) grazing a perennial ryegrass-dominated sward. Grass and Forage Science, v. 53, n. 1, p. 19-30, 1998.

https://doi.org/10.1046/j.1365-

2494.1998.00099.x

BARBOSA, R.A.; NASCIMENTO JÚNIOR, D.D.; EUCLIDES, V.P.B.; SILVA, S.D.; ZIMMER, A.H.; TORRES JÚNIOR, R.D.A. Capim-tanzânia submetido a combinações entre intensidade e freqüência de pastejo. Pesquisa Agropecuária Brasileira, v. 42, n. 3, p. 329-340, 2007. https://doi.org/10.1590/S0100$\underline{204 \times 2007000300005}$

BAUMONT, R.; COHEN-SALMON, D.; PRACHE, S.; SAUVANT, D. A mechanistic model of intake and grazing behaviour in sheep integrating sward architecture and animal decisions. Animal Feed Science and Technology, v. 112, n. 1, p. 5-28,
2004.

https://doi.org/10.1016/i.anifeedsci.2003.10.005

BENVENUTTI, M. A.; GORDON, I. J.; POPPI, D. P.; CROWTHER, R.; SPINKS, W.; MORENO, F. C. The horizontal barrier effect of stems on the foraging behaviour of cattle grazing five tropical grasses. Livestock Science, v. 126, n. 1, p. 229-238, 2009. https://doi.org/10.1016/j.livsci.2009.07.006

BRISKE, D. D.; DERNER, J. D.; BROWN, J.R.; FUHLENDORF, S.D.; TEAGUE, W.R.; HAVSTAD, K.M.; WILLMS, W.D. Rotational grazing on rangelands: reconciliation of perception and experimental evidence. Rangeland Ecology \& Management, v. 61, n. 1, p. 3-17, 2008. https://doi.org/10.2111/06-159R.1

CARVALHO, P. C. F. Harry Stobbs Memorial Lecture: Can grazing behavior support innovations in grassland management?. Tropical Grasslands-Forrajes Tropicales, v. 1, n. 2, p. 137155, 2013.

CARVALHO, P.C.D.F.; TRINDADE, J.K.D.; MEZZALIRA, J.C.; POLI, C.H.E.C.; NABINGER, C.; GENRO, T.C.M.; GONDA, H. L. Do bocado ao pastoreio de precisão: compreendendo a interface planta-animal para explorar a multifuncionalidade das pastagens. Revista brasileira de zootecnia, Viçosa,v. 38, supl. esp., p. 109-122, 2009.

CHACON, E.; STOBBS, T.H.I. Influence of progressive defoliation of a grass sward on the eating behaviour of cattle. Crop and Pasture Science, v. 27, n. 5, p. 709-727, 1976. https://doi.org/10.1071/AR9760709

CHIRAT, G.; GROOT, J. C.; MESSAD, S.; BOCQUIER, F.; ICKOWICZ, A. Instantaneous intake rate of free-grazing cattle as affected by herbage characteristics in heterogeneous tropical agropastoral landscapes. Applied Animal Behaviour Science, v. 157, p. 48-60, 2014. https://doi.org/10.1016/i.applanim.2014.06.003

CURLL, M. L.; WILKINS, R. J. Frequency and severity of defoliation of grass and clover by sheep at different stocking rates. Grass and forage science, v. 37, n. 4, p. 291-297, 1982. https://doi.org/10.1111/j.1365-

2494.1982.tb01609.x 
DERNER, J.D.; GILLEN, R.L.; MCCOLLUM, F.T.; TATE, K.W. Little bluestem tiller defoliation patterns under continuous and rotational grazing. Journal of Range Management, p. 220225, 1994. https://doi.org/10.2307 / 4003020

DRESCHER, M.; HEITKÖNIG, I. M.; RAATS, J. G.; PRINS, H. H. The role of grass stems as structural foraging deterrents and their effects on the foraging behaviour of cattle. Applied Animal Behaviour Science, v. 101, n. 1, p. 10-26, 2006. https://doi.org/10.1016/j.applanim.2006.01.011

FONSECA, L.; MEZZALIRA, J.C.; BREMM, C.; GONDA, H. L.; CARVALHO, P.D.F. Management targets for maximising the short-term herbage intake rate of cattle grazing in Sorghum bicolor. Livestock Science, v. 145 , n. 1, p. 205211, 2012. https://doi.org/10.1016/j.livsci.2012.02.003

GONÇALVES, A.C. Características morfogênicas e padrões de desfolhação em pastos de capim Marandu submetidos a regimes de lotação contínua. 2002. Tese (Doutorado) - Universidade de São Paulo, 2002.

GORDON, lain J. Browsing and grazing ruminants: are they different beasts? Forest Ecology and Management, v. 181, n. 1, p. 13-21, 2003. https://doi.org/10.1016/S0378-1127(03)00124-5

GRIFFITHS, W.M.; HODGSON, J.; ARNOLD, G.C. The influence of sward canopy structure on foraging decisions by grazing cattle. II. Regulation of bite depth. Grass and Forage Science, v. 58, n.2, p.125-137, 2003. https://doi.org/10.1046/i.1365-

2494.2003.00361.x

HODGSON, J. The frequency of defoliation of individual tillers in a set-stocked sward. Grass and Forage Science, v. 21, n. 4, p. 258-263, 1966. https://doi.org/10.1111/j.1365-

2494.1966.tb00483.x

HODGSON, J. The significance of sward characteristics in the management of temperate sown pastures. In: INTERNATIONAL GRASSLAND CONGRESS. Procedings [...] 1985. p. 63-66.

HODGSON, J. Grazing management. Science into practice. Longman, 1990.
HODGSON, J; CLARK, D. A.; MITCHELL, R. J. Foraging behavior in grazing animals and its impact on plant communities. Forage quality, evaluation, and utilization, p. 796-827, 1994.

LEMAIRE, G.; DA SILVA, S. C.; AGNUSDEI, M.; WADE, M.; HODGSON, J. Interactions between leaf lifespan and defoliation frequency in temperate and tropical pastures: a review. Grass and Forage Science, v. 64, n. 4, p. 341-353, 2009. https://doi.org/10.1111/j.1365-

2494.2009.00707.x

MAZZANTI, A.; LEMAIRE, G. Effect of nitrogen fertilization on herbage production of tall fescue swards continuously grazed by sheep. 2 . Consumption and efficiency of herbage utilization. Grass and forage Science, v. 49, n. 3, p. 352-359, 1994. https://doi.org/10.1111/i.13652494.1994.tb02010.x

MEZZALIRA, J.C.; CARVALHO, P.C.D.F.; FONSECA, L.; BREMM,C.; CANGIANO,C.; GONDA, H.L.; LACA, E. A. Behavioural mechanisms of intake rate by heifers grazing swards of contrasting structures. Applied Animal Behaviour Science, v.153, p.1-9, 2014. https://doi.org/10.1016/j.applanim.2013.12.014

MIQUELOTO, T. Frequência e severidade de desfolhação em pastos de Brachiaria humidicola sob lotação contínua. 2013. Dissertação (Mestrado em Ciência Animal) - Universidade do Estado de Santa Catarina, Lages, 2013.

NABINGER, C.; PONTES, L. da S. Morfogênese de plantas forrageiras e estrutura do pasto. Reunião anual da sociedade brasileira de zootecnia, v. 38, p. 755-771, 2001.

PALHANO, A. L.; CARVALHO, P. D. F.; DITTRICH, J. R.; MORAES, A. D.; BARRETO, M. Z.; SANTOS, M. D. Estrutura da pastagem e padrões de desfolhação em capim-mombaça em diferentes alturas do dossel forrageiro. Revista Brasileira de Zootecnia, v. 34, n. 6, p. 1860-1870, 2005.

PIERSON, F. B.; SCARNECCHIA, D. L. Defoliation of intermediate wheatgrass under seasonal and short-duration grazing. Journal of Range Management, $\quad$ p.228-232, 1987. http://dx.doi.org/10.2307/ 3899084 
RODOLFO, G. R; SCHMITT, D; DIAS, K. M.; SBRISSIA, A. F. Levels of defoliation and regrowth dynamics in elephant grass swards. Ciência Rural, v.45, n.7, p.1299-1304, 2015. http://dx.doi.org/10.1590/0103-8478cr20141094

ROMERA, A.J.; BURGES, J.C.; GREGORINI, P.; AGNUSDEI, M.G. Morphological components of Thynopirum ponticum tillers and their contribution to the diet of cattle grazing at contrasting herbage allowances. Livestock Science, v. 150, n. 1, p. 284-292, 2012. https://doi.org/10.1016/i.livsci.2012.09.013

SBRISSIA, A. F.; SILVA, S. C.; NASCIMENTO JÚNIOR D.; PEREIRA, L. E. T. Crescimento da planta forrageira: aspectos relativos ao acúmulo e valor nutritivo da forragem. In: SIMPÓSIO SOBRE MANEJO DA PASTAGEM. Anais [...] v. 25, p. 37, 2009

SILVA, C.J.A.; DITTRICH, J.R.; MONTEIRO, A.L.G.; DE MORAES, A.; DE BARROS, C.S.; DE OLIVEIRA, E.B. Preferência de caprinos em pastejo: efeito da altura de dosséis das forrageiras aruana e hemártria. Ciência Animal Brasileira, v. 10, n. 3, p. 698-710, 2009.

SILVA, S. C.; CARVALHO, P.C.F. Foraging behaviour and herbage intake in the favourable tropics/sub-tropics. In: McGILLOWAY, D. A. (Ed.) Grassland: a global resource. Wageningen: Wageningen Academic, 2005. p. 81-95.

STOBBS, T. H. The effect of plant structure on the intake of tropical pastures. I. Variation in the bite size of grazing cattle. Crop and Pasture Science, v.24, n.6, p.809-819, 1973. https://doi.org/10.1071/AR9730809

TUÑON, G.; KENNEDY, E.; HORAN, B.; HENNESSY, D.; LOPEZ-VILLALOBOS, N.; KEMP, P.; O'DONOVAN, M. Effect of grazing severity on perennial ryegrass herbage production and sward structural characteristics throughout an entire grazing season. Grass and Forage Science, v.69, n.1, p.104-118, 2014. https://doi.org/10.1111/gfs.12048

WADE, M. H. Factors affecting the availability of vegetative Lolium perenne to grazing dairy cows with special reference to sward characteristics, stocking rate and grazing method. 1991. Tese (Doutorado), 1991.
Recebido para publicação em 11/12/2018

Revisado em 14/01/2019

Aceito em 16/01/2019 